\title{
The Effect Organizational Culture and Total Quality Management Practices in Secondary School Performance of Abu Dhabi
}

\author{
Khaled Sultan Alhosani \\ Faculty of Management and Economics, University Pendidikan Sultan Idris, Tanjum Malim, Malaysia
}

Kamarul Bahari Bin Yaakub

$\mathrm{PhD}$, Faculty of Management and Economics, University Pendidikan Sultan Idris, Tanjum Malim, Malaysia

\begin{abstract}
The objective of this study was to investigate the effect of organizational culture and total quality management practices on secondary school performance in Abu Dhabi. Quantitative research design was adopted to obtain information from respondents. A total of 320 teachers were selected as a sample through the stratified random sampling method. Data analysis using structural equation modelling was used to determine the relationship between total quality management and secondary school performance.
\end{abstract}

Keywords: Organization, Culture, Performance, Total Quality Management

\section{Introduction}

The United Arab Emirate popularly called UAE became a country in 1971 with the alliance of seven Emirates (Abu Dhabi, Dubai, Sharjah, Ajman, Um Al Quwain, Ras Al-Khaimah and Fujairah.). In 1972, Ras Al-Khaimah emirate joined them to make seven Emirates. Self-education was taking place in each of the emirate before alliance in 1971 (Alhebsi, Pettaway \& Waller, 2015). The educational system often placed a strong emphasis on religious instruction and the acquisition of knowledge through interaction with others. Apprenticeships were a very common means of transferring skill-based knowledge. Much information was passed down from generation to generation through oral and written contexts. Traditional educational include teacher-student relationships encourage. There are four form of traditional education in UAE which to include, (1) Mutawa and the Katateeb, (2) Educational Circles, (3) Semi-Organized Education and (4) the Modern Educational System (Alnabah, 1996).

The variables are used in this study, total quality management (TQM), organizational culture (OC) and secondary school performance. The TQM consist of five dimensions. They are: school leadership, students focus, training, knowledge and process management and strategic quality planning.

Beside this, TQM improve organizational the productivity of workers to produce quality of product to meet customers satisfaction (Suleman \& Gul, 2015). Therefore, organizational culture is the values, beliefs, assumption and good ways of interacting that will lead to psychological environment of an organization. Also, organization culture contain an organization expectation philosophy, vast experience as well as those values that promote good conduct among the workers. As a matter of fact, culture is based on rule and regulation, customs and share attitude which has been in existence for so long (Mahmood, Qadeer \& Ahmed, 2015).

Again, organizational culture often called corporate culture because it affects the overall organizational performance and productivity, guide on customers care and service, improve product quality, punctuality and continuous care for the organization (Aminbeidokhti, Jamshidi \& Mohammadi Hoseini, 2016). In fact, organizational culture is characterized with commitment of workers to the objectives formulated, the extent of information sharing and power decentralization from the top management, decision making, new ideas and how they interact with outside world.

Hence, in order for schools in Abu Dhabi to meet high performance, the Irtiqaa program was introduced by the ADEK to address some of the problems affecting the school system. Before this programmer was launched, teachers employed in the system do not understand how quality will takes in the school. Apart from this, the organization observed that some 
teachers are less committed to teaching profession which has affected overall quality of education in the country (ADEK). Because of this, Irtiqaa program has been able to provide trainees with effective techniques, traits of influential personality assessment skills that they need, and build a complete set of competencies among the teacher, given the mentor trainees a better leadership roles in the future through participating in evaluation of schools, working within the Abu Dhabi emirate. This is why Irtiqaa program comes in to ameliorate the problems affecting secondary schools in Abu Dhabi (ADEK).

On the other hand, secondary school performance contain variables input such as teachers' contribution and professionalism, students' performance in and outside the school, leadership styles of the principal all determine school effectiveness. Growing bodies of knowledge observed that the outstanding schools in developed country are help with the quality teachers recruited. Without the quality management in the school system, quality would not be achievable.

\section{Problem statement:}

Secondary School performance is the main key of school organization's success in the UAE educational sectors. As the main key, the performance of secondary school comes from the teachers' genuineness which considered as being the most challenging of the secondary school operations (Gay, 2002). As TQM and OC play useful role in the organization, quality education in UAE had not been improve as expected. According to the results released by the emirate standardized test (EMSAT) that external examinations taking by these students' before they will enter universities were also poor (Gallagher, 2011). Some of these students cannot even get into university to study. The policy makers and stakeholders in education were concern about what might cause poor performance of these students. In fact, efforts has been taken to revert this situation but it has not be fruit. According to director of UAE ministry of education, Dr. Abdullah Al-Khanbashi (Farah \& Ridge, 2009; Blaik Hourani \& Litz, 2016) revealed that $68 \%$ of these students cannot enter universities to have a course (Blaik Hourani \& Litz, 2016). Therefore, if this problem is not solve on time the country education in future is in chaos (MOE, 2017 ) Although, the performance was not so bad but ADEK and government expecting more performance than previous one. The UAE's Ministry of Education (MOE) developed Education 2020 strategy, which is a series of ambitious five-year plans 2017-2021 designed to bring significant qualitative improvement in the education system, , as well as curriculum revision, including teaching math and science in English, are all part of the strategy. A key area of focus has been to transform K-12 programmes, to ensure that students are fully prepared to attend universities around the world and compete in the global marketplace The government promoted technology in schools to foster future employment and 21st century among today's youth, in line with its strategy to introduce computers and tablets in all schools. Ministry of Education launched a strategic plan for 2017-2021 to develop an innovative education system for building a knowledgeable and globally competitive society. The system will include all age groups to be able to meet future labour market demand. It shall ensure quality of the output of Ministry of Education and provide best services for internal and external customers. (MOE.2019).

\section{Methods:}

The research used for this study quantitative approach. This means that this study adopted quantitative method. The reason the researcher used quantitative research is because of the fact that, the researcher want to use questionnaire to obtain data from respondents. This is why Creswell (2017) defined quantitative method as technique that try to get relevant information from the participant in order to be make an inference. Quantitative method is appropriate for this study for the purpose of determining the relationship between total quality management and secondary schools' performance with organizational culture as a mediator in Abu Dhabi.

Population and sampling methods:

The population for this study will be school of all secondary schools in Abu Dhabi Island only. For instance, there three regions formed Abu Dhabi emirate. The three regions are Abu Dhabi zone, Al-Ain zone and Al-Dhafra zone. The total number of staff according to (Ministry of Education, 2019) is 1984 employees in secondary schools and total number of secondary schools are 28. The teachers in secondary schools comprise of principal, teachers, HOD and Vice Principal. (ADEK, 2017). Table 3.1 shows the Population of respondents for the study. The Cronbach Alpha was used to measure the response of sample. It was distributed 30 participant from selected schools. The outcomes it was secondary school performance. 
Instruments:

\begin{tabular}{|l|l|}
\hline Dimensions & No \\
\hline organizational culture & 25 \\
\hline total quality management & 20 \\
\hline secondary school PERFORMCA & 10 \\
\hline Total & 55 \\
\hline
\end{tabular}

\section{Conclusion}

The study gives understandings in to the impact of organization culture on the total quality management practices in the and secondary school performance in Abu Dhabi. It is imperative to adjudge the utilization of culture on total management process. The study finding the Organization Culture have significant relationship with total quality management. In addition to the established relationship between the TQM implementation and organisational performance improvement, it can be concluded that secondary school performance in Abu Dhabi can achieve better performance when the TQM philosophy is in place. Such improved performance can be seen as aggregated improvement in the quality of work. The TQM variable was operationalised as a latent construct. Therefore, it was not possible to understand the role of each TQM practice on the firm performance, and how it could be impacted by organisational culture. The future research would benefit from disaggregating these TQM practices to understand their relationships with other schools.

\section{References}

[1] Alhebsi, A., Pettaway, L., \& Waller, L. (2015). A history of education in the United Arab Emirates and Trucial Shiekdoms. The Global E-learning Journal, 4(1), 1-6.

[2] Alnabah, N. (1996). Education in the United Arab Emirates. Abu Dhabi, UAE: Alflah .

[3] Suleman, Q., \& Gul, R. (2015). Challenges to successful total quality management implementation in public secondary schools: A case study of Kohat District, Pakistan. Journal of Education and Practice, 6(15), 123-134.

[4] Mahmood, S., Qadeer, F., \& Ahmed, A. (2015). The role of organizational learning in understanding relationship between total quality management and organizational performance. Retrieved from: https://www.researchgate.net/publication/292970979_The_Role_of_Organizational_Learning_in_Understandin g_Relationship_between_Total_Quality_Management_and_Organizational_Performance.

[5] Aminbeidokhti, A., Jamshidi, L., \& Mohammadi Hoseini, A. (2016). The effect of the total quality management on organizational innovation in higher education mediated by organizational learning. Studies in Higher Education, 41(7), 1153-1166.

[6] Gay, G. (2002). Preparing for culturally responsive teaching. Journal of teacher education, 53(2), 106-116.

[7] Gallagher, K. (2011). Bilingual education in the UAE: factors, variables and critical questions. Education, Business and Society: Contemporary Middle Eastern Issues, 4(1), 62-79.

[8] Farah, S., \& Ridge, N. (2009). Challenges to Curriculum Development in the UAE. Dubai School of Government, Dubai. Retrieved from http:/www.mbrsg.ae/...6e75.../challenge-to-curriculum-development-in-the-UAE

[9] Blaik Hourani, R., \& Litz, D. (2016). Perceptions of the school self-evaluation process: The case of Abu Dhabi. School Leadership \& Management, 36(3), 247-270.

[10] Ministry of Education, The Evolution of Education in the UAE, 2017; (http://www.moe.gov.ae/ English/Pages/UaeEduH.aspx).

[11] Ministry of Education, The Quality education in the UAE, 2019; retrieved (https://www.government.ae/en/aboutthe-uae/leaving-no-one-behind/4qualityeducation).

[12] Creswell, J. W., \& Poth, C. N. (2017). Qualitative inquiry and research design: Choosing among five approaches. Sage publications. 